DOI 10.23859/2587-8352-2018-2-1-2

UDC 930

\section{Olga Solodyankina}

Doctor of Historical Sciences, Professor Cherepovets State University

(Cherepovets, Russia)

olga_solodiankin@mail.ru

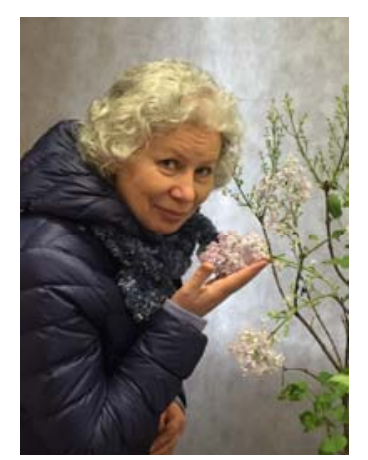

\title{
Animal history: New research opportunities
}

Annotation. The article contains analysis of the modern trends in historiography, in which there has been observed another methodological 'change of course' described as 'animal turn'. The traditional anthropocentrism of historical research, in the author's opinion, is replaced by the study of relationships between man and animals in line with economic, social and cultural history, military history, intellectual history, the history of science, the history of medicine and other fields of historical knowledge. The new research on the history of human-animal relationships focuses on how these interspecific relationships (animal-human relations) are built, what they are, bearing in mind the effects that such relations might have.

Keywords: human-animal relationships, foreign historiography, future development of historical science, turn to animals, 'animal turn'

\section{Introduction}

The traditional definition of history implies that this science is related to the past social reality, and that the main subject of history is res gestae ${ }^{1}-$ the actions of people, i.e. social actions. The modern time got us used to such an interpretation of historical science, although the pre-Renaissance paradigm of history included in the subject of history, apart from the actual social reality, both the Divine reality and the natural one ${ }^{2}$. The world of the post-Renaissance man has become anthropocentric, and then individualistic. The growing practical (more often - economic) successes of the mankind and the progress in the natural sciences made increasingly popular the

${ }^{1}$ Res gestae - the Latin term, meaning 'things done', is sometimes translated as 'history' (in the sense of totality of the facts from the past)

${ }^{2}$ About the change in the subject of history, see details in Savelieva I.M., Poletaev A.V. Knowledge of the Past: Theory and History: In 2 Vol. V.1: Designing the Past. St Peterburg, 2003 (In Russian). 
representations of the human being as the pinnacle of the world, the crown of creation and contributed to the domination of human-centered designs in the natural sciences. This narrowing of the subject of history to exclusively human history was combined with the simultaneous widening of the research field, affecting one after another all the new aspects of human existence - from political history to economic, social, psychohistory, cultural history, the history of mentalities, the history of everyday life, etc. However, at the center of all these 'new histories" ${ }^{3}$ was still a man. Does this anthropocentrism of history correspond to the realities of the $21^{\text {st }}$ century? What opportunities open to the historical science in overcoming this subject 'framework' of anthropocentrism? The article will be answering these questions.

\section{Main body}

In the realities of the modern world, the processes that are almost unmanageable (or hardly manageable at all) to the humans, especially the influence and decisions of a single individual, are becoming more and more noticeable. Such processes include climate change, environmental disasters (of different scale, from local to global), introduction of biotechnologies, spread of new media (social networks), the effects of globalization, etc. The Humanities are trying to respond to these challenges of our time. Such answers can be attributed to the ideas about the 'end of history' developed after Fukuyama's ${ }^{4}$ sensational article, and all sorts of methodological 'turns': linguistic, anthropological, visual, 'turning to material', etc. Each of these 'turns' is associated with some degree of implementing the idea of interdisciplinarity or, more precisely, trans-disciplinarity, when the application of approaches in different sciences should have (and in many cases, does have) a synergistic effect.

By implementing the message of interdisciplinarity, historians 'implanted' the methods of socio-humanitarian sciences - sociology, anthropology, linguistics, etc. into their research practices. One by one, such 'junctions', transitional spaces within the general group of scientific disciplines, called humanities, are filled. Each of methodological 'turns' led to serious breakthroughs in the field of accumulation of scientific knowledge; scientific publications of a fundamentally higher level appeared, and the new problems of research were outlined. Naturally, each of such 'breakthroughs' required new knowledge from historians, with new approaches, mastering a new language of historiography. The frequency of 'turns' suggests that historians have learned to respond to these challenges.

${ }^{3}$ In the historical science of the $20^{\text {th }}$ century, many new areas of research practice received the mandatory 'appendage' in the titles represented by the word 'new': new social history, new intellectual history, new cultural history, etc.

4 Fukuiama F. Konets istorii? [End of history?]. Voprosy filosofii [Issues of Philosophy], 1990, no. 3, pp. 134-1489 (in Russian). In English see: Fukuyama, Francis (1989). 'The End of History?' The National Interest (16): pp. 3-18. 
However, the potential for expanding the subject field of history is much less effective. Is it binding upon history to limit its interests to the 'man-man' interaction field?

The social sciences have identified three main areas of human interaction with the outside world: these are the man-machine, man-nature and man-human interactions. The latter area of interaction is undoubtedly the subject of history research, but what is the relationship of history with the two other trends? The history of technology deals with the interactions between 'man-technology' and 'man-material objects', and it is noteworthy that for most representatives of the historical-scientific community, this subdiscipline rather refers to a wider field of 'technology' rather than 'history'. In historical science, the broadest cluster of history of human-nature interaction was integrated; overcoming certain resistance of historians-traditionalists, the ecological history took its shape. However, the emphasis in environmental history is either on the 'fit in' of a person in the natural environment, or on the sad consequences of human intervention in the environment, i.e. environmental disasters. The living things of the natural world, living creatures, turn out to be exclusively objects (and, as a rule, auxiliary ones) in the scientific studies. But is this limited role of animals appropriate in the context of human history? Is it time to revise the subject field of history, abandoning anthropocentrism ${ }^{5}$ and adding the history of animals to it, of course, without substituting it for zoology and paleozoology?

The foreign historiography unequivocally positively responded to this challenge of our time, intensively expanding the research topic within the general trend of 'Human-Animal Studies'. American universities offer a wide range of subjects dedicated to various aspects of history of human-animal relationships ${ }^{6}$. In the Englishlanguage historiography, the number of research projects devoted to these or the aspects of human-animal interaction is also increasing in avalanche, and the designation for this trend of historical studies, the 'animal turn' which is 'turn to animals', has been provided.

One cannot say that animals are a completely new plot in the world history. Undoubtedly, in the historical studies, animals were also present before: in the form of the process of domestication of animals, or war horses and elephants participating in the battles, or favorite animals of certain outstanding figures, or, more often, in the form of livestock. The innovation is in the change of research approaches and in shifting the perspective of the problem. Let us characterize these innovations in relation to the main sub-disciplines of history.

\footnotetext{
${ }^{5}$ On the critical attitude towards anthropocentrism, see Boddice Rob (ed.) Anthropocentrism: Humans, Animals, Environments. Leiden; Boston: Brill, 2011.

${ }^{6}$ For a list of universities where such courses are taught, the names of lecturers and brief annotations of the courses, please visit www.animalsandsociety.org/human-animal-studies/courses/hascourses-in-history
} 
In the framework of economic history, the history of taming and domestication of animals, the history of the use of animals in human economic activities are studied. Here the emphasis is on studying how animals turned into goods, what was used - in food, for making clothes, to produce other objects; how animals were used, which animals were used mainly in the cities, and which ones - in the rural areas, how the attitude towards animals changed as the period of joint 'living' with them increased". Perhaps, this is the segment of the history of animals that has been studied most fully, although using poststructuralist theories ${ }^{8}$ or within the framework of the "turn to the material', the research breakthroughs are also possible here, such as for the study of the reverse process - the taming of the human being by the animals ${ }^{9}$. In addition, another aspect of economic activity relates to the formation of the market of goods and services for domestic animals, the animal care industry: animal care products, special food for animals, animal medicine, advertising, the dynamics of market formation in different countries ${ }^{10}$, financial value of animals, etc. Exceptionally interesting conclusions can be drawn based on studying the history of the market for exotic animals, where for a long time the interests of naturalists, collectors and simply amateurs intertwined. Exotic animals often became gifts from one ruler to another, forcing them to create special facilities for these animals (for example, the elephant in St Petersburg during the reign of Anna Ioannovna), to think about their care and maintenance - which, under the conditions of poor development of scientific knowledge, was a difficult, and sometimes insoluble economic and scientific problem. The history of zoological gardens and zoos can be considered in the context of history related to economic activity, as part of the infrastructure that attracts tourists. Animal tourism has gained popularity for some time now, and the study of this phenomenon (like a safari) in historical dynamics also becomes the task of history ${ }^{11}$.

Similarly, in intellectual history, another subject niche is found, associated with animals: this would be the study of the category 'animal' in historical dynamics, the history of reasoning about animals as something opposing or, conversely, connected with the man. Defining its relationship / antithesis to the animal, the person reflected on their own nature, the society, the state (which were often presented as giant living

7 See for example: Rowley-Conwy Peter; Serjeantson D.; Halstead Paul (eds.). Economic zooarchaeology: studies in hunting, herding and early agriculture. Oxford; Havertown, 2017.

${ }^{8}$ See for example: Taylor N., Hamilton L. Animals at Work: Identity, Politics and Culture in Work with Animals. Leiden, 2013.

${ }^{9}$ See for example: Grier K.C. Pets in America: A History. Chapel Hill, 2006; Hobgood-Oster Laura. A Dog's History of the World: Canines and the Domestication of Humans. Waco, 2014.

${ }^{10}$ For example, in the US and the UK, the industry for dog care products and services has existed since the $19^{\text {th }}$ century, whereas the market for cat supplies and cat sitting services took shape much later.

${ }^{11}$ See for example: Knight J. Herding Monkeys to Paradise: How Macaque Troops are Managed for Tourism in Japan. Leiden, 2011. 
organisms), politics, religion and similar existentially important topics ${ }^{12}$. Here one can find stories related to comprehension of animal rights ${ }^{13}$, representation of man as an animal among other animals ${ }^{14}$ and so on. Within the framework of this subdiscipline - the intellectual history - the main studies of the history of animals are undoubtedly still ahead.

The history of science opens the widest scope for studies related to animals. Here, at the intersection with intellectual history, there are works devoted to the subjects related to the development of animal sciences, study of animal behavior in parallel with formation of social theories ${ }^{15}$. It is interesting to trace which theories related to the man, their behavior, grew out of the study of animal behavior, what place in the conceptual world of social sciences would be taken by the concept of 'animal origin', 'natural instincts', etc. At the same time, scientific hypotheses could be transferred from one object to another - from animals to humans (most often), but a reverse order was also possible - from a person to an animal. Thus, in the $19^{\text {th }}$ century, the approach, according to which the inborn cretinism of a person was obvious 'at first sight', was widely spread; another thing was that in the city bustle, it was possible 'at first sight' to distinguish the 'owner's' dog from a stray one ${ }^{16}$.

From the point of view of cultural history, animals are important actors in human history (for example, eagles, whose flight on the eve of a battle or adoption of a fateful decision was perceived as a sign from above - the sign of a future victory or a defeat). The symbolism of animals is incredibly diverse; different peoples put different symbolic meanings in the images of the same animals, and identical meanings were transmitted in different cultures by the images of various animals. Heraldic symbols were images of both real and mythical animals: lions, eagles, unicorns, uroboros, etc. In the meantime, animals are victims in the human culture (animal sacrifices have been characteristic of many human societies and religions). The cultural representations of animals - in texts, language and works of art - provide almost inexhaustible basis for scientific research. Correlating oneself with this or that animal, religious beliefs regarding 'sacredness' of certain animals, cultural traditions of inter-

${ }^{12}$ For example: Manning Au. and Serpell J. (eds.) Animals and human society: changing perspectives. London; New York, 1994; Swart S. and van Sittert L. (eds.) Canis Africanis: A dog history of South Africa. Leiden, 2008.

${ }^{13}$ Kemmerer L. In Search of Consistency: Ethics, Animals, and the Minimize Harm Maxim. Leiden; Boston, 2006; Munro Lyle. Confronting Cruelty-Moral: Orthodoxy and the Challenge of the Animal Rights Movement. Leiden; Boston, 2005.

${ }_{15}^{14}$ Simmons L., Armstrong P. (eds.) Knowing Animals. Leiden; Boston, 2007

15 Harraway Donna J. The Companion Species Manifesto: Dogs, People, and Significant Otherness. Chicago, 2003.

${ }^{16}$ Pearson Ch. The Late Nineteenth-Century Separation of Stray and Pet Dogs. Available at: https://pethistories.wordpress.com/2017/09/14/the-late-nineteenth-century-separation-of-stray-andpet-dogs/. Date of access 01.02.2018. 
preting male / female through the rational / irrational, human / animal, canine / feline ${ }^{17}$, etc. - these would be the possible plots for the study of the new cultural history. In the framework of this sub-discipline of history, there are certain achievements ${ }^{18}$, but the 'visual turn' accompanying its close attention to the surviving images ${ }^{19}$ opens new research opportunities in this segment as well.

In the framework of military history, animals are also being studied. Researchers are trying to cover several topics related to the participation of animals in human wars, as well as their preparation for future military activities. This examines not only the training process, but also the new opportunities for military tactics and even strategies that were suggested in case of using animals (horses for a long time, elephants in the wars of antiquity, dolphins, seals and even bees were used quite recently, and so on $)^{20}$. Animals could act as a source of disease to hit the enemy, served as a means of communication (pigeons, dogs), caught rats and mice that could damage the facilities of the military infrastructure (cats), were used as rescuers and as 'bone polishers' (dogs). The animals went into space long before people did, which was also part of the military program ${ }^{21}$. At the intersection with the cultural history, memorial and reward practices are explored - how to bury and honor animals heroically fallen in the battles, when these practices appeared and how their content changed over time ${ }^{22}$.

${ }^{17}$ Such dichotomies are characteristic, for example, of the British cultural tradition.

${ }^{18}$ Ackerman-Lieberman Phillip Isaac and Zalashik Rakefet (eds.) A Jew's best friend?: the image of the dog throughout Jewish history. Brighton; Portland, 2013; Alves Abel A. The Animals of Spain: An Introduction to Imperial Perceptions and Human Interaction with Other Animals, 14921826. Boston, 2011; Choyke Alice M. and Jaritz Gerhard (eds.) Animaltown: beasts in medieval urban space. Oxford, 2017; Costlow Jane T. and Loxton Hovard. 99 Lives: Cats in History, Legend and Literature. San Francisco, 1998; Nelson A. Other animals: beyond the human in Russian culture and history. Pittsburgh, 2010; Nelson A. A Hearth for a Dog: The Paradoxes of Soviet Pet Keeping, Ed. Siegelbaum L. in Borders of Socialism: Private Spheres of Soviet Russia. Basingstoke, 2006, pp. 124-126; Taylor Nik, Signal Tania. Theorizing animals: re-thinking humanimal relations. Leiden; Boston, 2011.

${ }^{19}$ See, for example, the work on the images of the Tasmanian 'tiger': Freeman Carol. Paper Tiger: A Visual History of the Thylacine. Leiden; Boston, 2010; or a selection of images of cats in the world culture: www.thegreatcat.org

${ }^{20}$ Hediger Ryan (ed.) Animals and War: Studies of Europe and North America. Boston, 2013.

21 Burgess C. and Dubbs C. Animals in Space: From Research Rockets to the Space Shuttle. Chichester, 2007; McNeill J.R. and Unger C.R. (eds.) Environmental Histories of the Cold War. New York, 2010; Nelson A. The legacy of Laika: celebrity, sacrifice and the Soviet space dogs. Brantz Dorothee (ed.) Beastly Natures: Animals, Humans, and the Study of History. Charlottesville, 2010, pp. 204-224; Turkina O. Soviet Space Dogs. London, 2014

${ }^{22}$ In 1943, the British established the medal of Maria Dickin (Dickin Medal) which is the highest military award for animals; from 1943 to 1949 the medal was awarded 54 times - to thirty-two pigeons, eighteen dogs, three horses and the ship's cat Simon; thus, were awarded the animals who had shown bravery or devotion in the service for people during World War II. The award was reinstated in 2000, and in December 2007 a reburial with full military honors was arranged as dedicated to the animals in the pet cemetery in Ilford-based PDSA (People's Dispensary for Sick Animals the UK' leading vet charity). 
The history of medicine, and to be more precisely, the new history of medicine also becomes a breakthrough point in the study of animals in the context of human history. Several aspects can be pointed out in this respect: animals as an object of laboratory trials and experiments, a kind of a simulator instead of a doctor / surgeon; animals as a source of diseases, a link in the chain in the spread of diseases; animals as a raw material in the production of medicines and preparations; communication with animals as part of a therapy; psychological features of interaction with animals ${ }^{23}$. Each of the possible aspects of the study presupposes a broader research problem, considering the space-time continuum. It is in this sphere (due to the specifics of the problems) that the greatest degree of amalgamation of the approaches and methods of various sciences can be expected, as an example, in the study of dog competence to understand human communication signals, as well as their ability to initiate contacts with the $\operatorname{man}^{24}$.

Animals also appear in studies on gender history, history of racial, national and other marginal communities, contributing to a more comprehensive study of the topic ${ }^{25}$. Animals have also been marginalized in many cases, whilst comparing the marginalities of humans and animals has a certain research potential.

The history of emotions is a growing trend in the last decade; emotions began to be regarded as a category of historical analysis. Studying animals in this respect also opens new possibilities: how animals were represented, what emotional influence they exerted; changing ideas about the expression of emotions in man and animals, the emotional value of communicating with the animal world ${ }^{26}$. Very popular was the projection of the emotional world of people onto the animal world, and from here one

${ }^{23}$ Nikol'skaia A.V. Vzaimodeistvie cheloveka s domashnimi zhivotnymi: teoriia, metodologiia, praktika [Human interaction with domestic animals: theory, methodology, practice]. Moscow: Pero, 2012; Melson Gail F. Psychology and the Study of Human-Animal Relationships. Society \& Animals, 2002, vol. 10, Issue 4, pp. 347-352. DOI: 10.1163/156853002320936791; McCardle Peggy [et all]. Animals in our lives: human-animal interaction in family, community, and therapeutic settings. Baltimore, 2011.

${ }^{24}$ Marshall-Pescini S. \& Kaminski J. The social dog: history and evolution. Kaminski J. \& Marshall-Pescini S. (eds.) The social dog: cognition and behavior. San Diego, 2014, pp. 3-34; Pettersson H., Kaminski J., Herrmann E. \& Tomasello M. Understanding of human communicative motives in domestic dogs. Applied Animal Behaviour Science, 2011, vol. 133, no. 3-4, pp. 235245; Horowitz Alexandra and Hecht July. Looking at dogs: moving from anthropocentrism to canid Umwelt. Horowitz Alexandra (ed.) Domestic Dog Cognition and Behavior: The Scientific Study of Canis Familiaris. Berlin, 2014, pp. 201-219.

${ }^{25}$ Haraway Donna J. Primate Visions: Gender, Race, and Nature in the World of Modern Science. New York and London, 1989.

${ }^{26}$ Pręgowski Michał Piotr (ed.) Companion Animals in Everyday Life: Situating HumanAnimal Engagement within Cultures. New York, 2016. 
could see the range of possible research topics in the historical context, which is incredibly wide ${ }^{27}$.

We are used to believe in the aphorism about the 'right person in the right place'; however modern historians argue using large factual material that it is equally important that animals are at the right time as well (in the case of rescue dogs or animalemotional friends), and this history of human relationships, in particular with dogs, accounted, according to various estimates, for 14 000-15 000 years. Within the framework of such a view of the history, it is necessary to mention the contribution of domestic animals to the history of the mankind ${ }^{28}$. As a minimal illustration of such influence on the animals, one can cite the story of rescuing the drowning Napoleon (during his return from Elba Island) by a Newfoundland dog and the inspiring role of dogs and cats in the works of their masters - Richard Wagner, Sigmund Freud, Alexander Bell and others.

\section{Summary}

The animal world has become the focus of attention of the scientists that specialize in the field of economic, social and cultural history, military history, intellectual history, history of science, history of medicine and other areas of historical knowledge, as the history of domestic animals and the dynamics of people's attitude towards them adds a lot to our understanding of the human life itself. The new research on the history of human-animal relations focuses on how these interspecies relations ('animals-humans' relations) are built as such, what they represent, bearing in mind the effects of such relations ${ }^{29}$. These works are essentially integrative; they use different approaches, a mix of themes and hypotheses ${ }^{30}$.

${ }^{27}$ See, for example: Solodiankina O.Iu. Reprezentatsii vlasti, 'ochelovechivanie' i voprosy bezopasnosti: sobaki v povsednevnoi zhizni rossiiskoi imperatorskoi sem'i [Representations of power, 'humanization' and security issues: dogs in the everyday life of the Russian imperial family] in IStoriia povsednevnosti [The history of everyday life], 2017, no. 2(4), pp. 9-22.

28 Coren St. The Pawprints of History: Dogs and the Course of Human Events. New York; London, 2003; Derr M. A Dog's History of America: How Our Best Friend Explored, Conquered, and Settled a Continent. New York, 2013; Stall Sam. 100 Dogs Who Changed Civilization: History's Most Influential Canines. Philadelphia, 2007; Stall S. 100 Cats Who Changed Civilization: History's Most Influential Felines. Philadelphia; San Francisco, 2007; Vocelle L.A. Revered and Reviled: A Complete History of the Domestic Cat. Great Cat Publications, 2016; Kalda S. Of Cats and Men: Profiles of History's Great Cat-Loving Artists, Writers, Thinkers, and Statesmen. New York, 2017.

${ }^{29}$ Birke L., Hockenhull Jo (eds.) Crossing boundaries: investigating human-animal relationships. Leiden; Boston, 2012; Derr M. How the dog became the dog: from wolves to our best friends. New York, 2013.

${ }^{30}$ Hediger R., McFarland Sarah E. (eds.) Animals and agency: an interdisciplinary exploration. Boston, 2009; Kalof L. (ed.) The Oxford handbook of animal studies. New York, 2017; Tyler T., Rossini M. (eds.) Animal Encounters. Leiden, 2009. 
And although the animals occupied a huge niche in the history and, in particular, where a significant layer of literature ${ }^{31}$ is devoted to the contribution of dogs to the evolvement of the human being, the suggestions to rewrite the human history through the eyes of animals are still considered marginal.

\section{References}

1. Ackerman-Lieberman Phillip Isaac and Zalashik Rakefet (eds.) A Jew's best friend?: the image of the dog throughout Jewish history. Brighton; Portland: Sussex Academic Press, 2013. $283 \mathrm{p}$.

2. Alves Abel A. The Animals of Spain: An Introduction to Imperial Perceptions and Human Interaction with Other Animals, 1492-1826. Boston: Brill, 2011. 226 p.

3. Birke Lynda, Hockenhull Jo (eds.) Crossing boundaries: investigating human-animal relationships. Leiden; Boston: Brill, 2012. 260 p.

4. Boddice Rob (ed.) Anthropocentrism: Humans, Animals, Environments. Leiden; Boston: Brill, 2011. 348 p.

5. Burgess C. and Dubbs C. Animals in Space: From Research Rockets to the Space Shuttle. Chichester: Springer Science \& Business Media, 2007. 406 p.

6. Choyke Alice M. and Jaritz Gerhard (eds.) Animaltown: beasts in medieval urban space. Oxford: BAR Publishing, 2017. 209 p.

7. Cockram S. and Wells A. (eds.) Interspecies Interactions: Animals and Humans between the Middle Ages and Modernity. Abingdon; New York: Routledge, 2018. 242 p.

8. Coren St. The Pawprints of History: Dogs and the Course of Human Events. New York; London: Free Press, 2003. 322 p.

9. Costlow Jane T. and Nelson A. Other animals: beyond the human in Russian culture and history. Pittsburgh: University of Pittsburgh Press, 2010. 320 p.

10. Cummins Bryan D. Our debt to the dog: how the domestic dog helped shape human societies. Durham: Carolina Academic Press, 2013. 439 p.

11. Derr M. A Dog's History of America: How Our Best Friend Explored, Conquered, and Settled a Continent. New York: The Overlook Press, 2013. 380 p.

12. Derr Mark. How the dog became the dog: from wolves to our best friends. New York: Overlook Duckworth, 2013. 287 p.

13. Fagan Brian M. The intimate bond: how animals shaped human history. New York: Bloomsbury Press, 2016. 308 p.

14. Freeman C. Paper Tiger: A Visual History of the Thylacine. Leiden; Boston: Brill, 2010. $287 \mathrm{p}$.

15. Fukuiama F. Konets istorii? [End of history?]. Voprosy filosofii [Issues of Philosophy], 1990, no. 3, pp. 134-148.

16. Grier K.C. Pets in America: A History. Chapel Hill: University of North Carolina Press, 2006. 377 p.

${ }^{31}$ See, for example: Cockram Sarah and Wells Andrew (eds.) Interspecies Interactions: Animals and Humans between the Middle Ages and Modernity. Abingdon; New York, 2018; Cummins Bryan D. Our debt to the dog: how the domestic dog helped shape human societies. Durham, 2013; Fagan Brian M. The intimate bond: how animals shaped human history. New York, 2016. 
17. Haraway Donna J. Primate Visions: Gender, Race, and Nature in the World of Modern Science. New York and London: Routledge, 1989. 498 p.

18. Harraway Donna J. The Companion Species Manifesto: Dogs, People, and Significant Otherness. Chicago: University of Chicago Press, 2003. 60 p.

19. Hediger Ryan (ed.) Animals and War: Studies of Europe and North America. Boston: Brill, 2013. $268 \mathrm{p}$.

20. Hediger Ryan, McFarland Sarah E. (eds.) Animals and agency: an interdisciplinary exploration. Boston: Brill, 2009. 382 p.

21. Hobgood-Oster L. A Dog's History of the World: Canines and the Domestication of Humans. Waco: Baylor University Press, 2014. 188 p.

22. Horowitz Al. and Hecht J. Looking at dogs: moving from anthropocentrism to canid Umwelt. Horowitz Alexandra (ed.) Domestic Dog Cognition and Behavior: The Scientistfic Study of Canis Familiaris. Berlin: Springer, 2014, pp. 201-219.

23. Kalda Sam. Of Cats and Men: Profiles of History's Great Cat-Loving Artists, Writers, Thinkers, and Statesmen. New York: Ten Speed Press, 2017. 101 p.

24. Kalof L. (ed.) The Oxford handbook of animal studies. New York: Oxford University Press, 2017. $621 \mathrm{p}$.

25. Kemmerer L. In Search of Consistency: Ethics, Animals, and the Minimize Harm Maxim. Leiden; Boston: Brill, 2006. 542 p.

26. Knight J. Herding Monkeys to Paradise: How Macaque Troops are Managed for Tourism in Japan. Leiden: Brill, 2011. 628 p.

27. Loxton H. 99 Lives: Cats in History, Legend and Literature. San Francisco: Chronicle Books, 1998. 144 p.

28. Manning Au. and Serpell J. (eds.) Animals and human society: changing perspectives. London; New York: Routledge, 1994. 199 p.

29. McCardle Peggy [et all]. Animals in our lives: human-animal interaction in family, community, and therapeutic settings. Baltimore: Paul H. Brookes, 2011. 242 p.

30. McNeill J.R. and Unger C.R. (eds.) Environmental Histories of the Cold War. New York: Cambridge University Press, 2010. 362 p.

31. Marshall-Pescini S. \& Kaminski J. The social dog: history and evolution. Kaminski J. \& Marshall-Pescini S. (eds.) The social dog: cognition and behavior. San Diego: Academic Press Inc., 2014, pp. 3-34.

32. Melson Gail F. Psychology and the Study of Human-Animal Relationships. Society \& Animals, 2002, vol. 10, Issue 4, pp. 347-352. DOI: 10.1163/156853002320936791

33. Munro Lyle. Confronting Cruelty-Moral: Orthodoxy and the Challenge of the Animal Rights Movement. Leiden; Boston: Brill, 2005. 218 p.

34. Nelson A. A Hearth for a Dog: The Paradoxes of Soviet Pet Keeping. Siegelbaum L. (ed.) Borders of Socialism: Private Spheres of Soviet Russia. Basingstoke, 2006. pp. 124-126.

35. Nelson Amy. The legacy of Laika: celebrity, sacrifice and the Soviet space dogs. Brantz Dorothee (ed.) Beastly Natures: Animals, Humans, and the Study of History. Charlottesville: University of Virginia Press, 2010, pp. 204-224.

36. Nikol'skaia A.V. Vzaimodeistvie cheloveka s domashnimi zhivotnymi: teoriia, metodologiia, praktika [Human Interaction with Domestic Animals: Theory, Methodology, Practice]. Moscow: Pero, 2012. 452 p. 
37. Pearson Chris. The Late Nineteenth-Century Separation of Stray and Pet Dogs. Available at: https://pethistories.wordpress.com/2017/09/14/the-late-nineteenth-century-separation-of-strayand-pet-dogs/. Date of access 01.02.2018.

38. Pettersson H., Kaminski J., Herrmann E. \& Tomasello M. Understanding of human communicative motives in domestic dogs. Applied Animal Behaviour Science, 2011, vol. 133, no. 3-4, pp. 235-245.

39. Pręgowski Michał Piotr (ed.) Companion Animals in Everyday Life: Situating HumanAnimal Engagement within Cultures. New York: Palgrave: Macmillan, 2016. 313 p.

40. Rowley-Conwy Peter; Serjeantson D.; Halstead Paul (eds.) Economic zooarchaeology: studies in hunting, herding and early agriculture. Oxford; Havertown: Oxbow Books, 2017. 298 p.

41. Savel'eva I.M., Poletaev A.V. Znanie o proshlom: teoriia $i$ istoriia: v 2 t. T. 1: Konstruirovanie proshlogo [Knowledge of the Past: Theory and History: In 2 Volumes. Vol. 1: Designing the Past]. St Petersburg: Nauka, 2003. 632 p.

42. Simmons L., Armstrong P. (eds.) Knowing Animals. Leiden; Boston: Brill, 2007. 296 p.

43. Solodiankina O.Iu. Reprezentatsii vlasti, 'ochelovechivanie' i voprosy bezopasnosti: sobaki v povsednevnoi zhizni rossiiskoi imperatorskoi sem'i [Representations of power, 'humanization' and security issues: Dogs in the everyday life of the Imperial Family (the Romanovs)]. Istoriia povsednevnosti [The History of Everyday Life], 2017, no. 2(4), pp. 9-22.

44. Stall S. 100 Cats Who Changed Civilization: History's Most Influential Felines. Philadelphia: Quirk Books; San Francisco: Distributed by Chronicle Books, 2007. 175 p.

45. Stall S. 100 Dogs Who Changed Civilization: History's Most Influential Canines. Philadelphia: Quirk Books, 2007. 175 p.

46. Swart S., van Sittert Lance (eds.) Canis Africanis: A dog history of South Africa. Leiden: Brill, 2008. 295 p.

47. Taylor N., Hamilton L. Animals at Work: Identity, Politics and Culture in Work with Animals. Leiden: Brill, 2013. 210 p.

48. Taylor N., Signal T. Theorizing animals: re-thinking humanimal relations. Leiden; Boston: Brill, 2011. 293 p.

49. Turkina O. Soviet Space Dogs. London: FUEL Design \& Publishing, 2014. 237 p.

50. Tyler T., Rossini M. (eds.) Animal Encounters. Leiden: Brill, 2009. 266 p.

51. Vocelle L.A. Revered and Reviled: A Complete History of the Domestic Cat. Great Cat Publications, 2016. 416 p.

For citation: Solodyankina Olga Animal history: New research opportunities. Historia provinciae - the journal of regional history, 2018, vol. 2, no. 1, pp. 18-28. DOI: $10.23859 / 2587-8352-2018-2-1-2$ 